\title{
BEHAVIOR OF THE ESTUARINE DolPHIN, Sotalia guianensis, AT DOLPHIN BAY - PipA - Rio Grande do NorTe - BrazIL.
}

\author{
Janaina Pauline de ARAÚJO(1) \\ JOSÉ ZANON DE OLIVEIRA PASSAVANTE ${ }^{(1)}$ \\ ANTONIO DA SILVA SOUTO ${ }^{(2)}$
}

1 - Departamento de Oceanografia da UFPE

2 - Departamento de Zoologia da UFPE

\begin{abstract}
RESUMO
Há inúmeros trabalhos realizados com Sotalia guianensis, todavia somente alguns descrevem quantitativamente os comportamentos utilizados por estes animais no ambiente. Sendo assim o presente trabalho se reveste de uma grande importância, porquanto registra além de seu comportamento a presença de jovens no ambiente. O local de observação foi na Baía dos Golfinhos, em Pipa, município de Timbáu do Sul no Estado do Rio Grande do Norte. Os animais foram observados por 360 horas, realizados durantes os anos de 1995, 1996 e 2000, As formas comportamentais observadas foram: alimentação (caça e manipulação da presa); salto (total, parcial, mortal). O número registrados de golfinhos variou entre 1 e 8 . O maior número ocorreu pela manhã, sendo mais freqüentes nas baixa-mares. O número máximo de jovens foi três. o salto total é realizado com mais freqüência quando observa-se mais de três golfinhos na baía $(p<0,001)$. Os resultados mostram que, as estratégias comportamentais cambalhota, caudal, manipulação do alimento, periscópio e salto total, apresentam um maior índice com a participação dos filhotes $(\mathrm{p}<0,001)$
\end{abstract}

Palavras chave: Sotalia guianensis; comportamento animal, Baía dos Golfinhos.

\begin{abstract}
There are numerous papers dealing with the behavior of Sotalia guianensis. However, only a few describe quantitatively the strategies used by these animals. Therefore, the main objective of this study was to observe some behavioral strategies of the estuarine dolphin (Sotalia guianensis), indicating the most frequent ones and comparing them. Moreover, our aim was also to register the presence of young and their behavior. The work was carried out in Dolphin Bay (Pipa, municipality of Tibau do Sul, Rio Grande do Norte - Brazil). The animals were observed for 360 hours in 1995, 1996 and 2000. The observed forms of conduct were: feeding (chase and prey manipulation), leaps (total, partial and somersaults), tailslap, spy-hopping and surfing. The number of estuarine dolphin present ranged from one to eight animals. The maximum number of dolphins occurred in the morning, with the largest frequency being at low tide. The maximum number of young was three individuals, and the largest frequency was of only one young. The results showed that somersaults, tailslap, prey manipulation, spy-hopping and total leaping presented their largest frequency of occurrence when they included the presence of the young $(\mathrm{p}<0,001)$.
\end{abstract}

Key words: Sotalia guianensis, estuarine dolphin, behavior, Dolphin Bay, Pipa Beach.

Tropical Oceanography, Recife: v. 31, n. 2, p. 101-112, 2003. 


\section{INTRODUCTION}

The estuarine dolphin Sotalia guianensis is a relatively small cetacean. This species occurs along the western Atlantic coastal waters of South and Central America. The northern limit of its distribution is Honduras (da Silva \& Best, 1996) and the southern is Santa Catarina (Simões Lopes, 1987). This species is classified by the World Conservation Union (IUCN) (2000) as "data deficient" and it is on appendix I of CITES' “Convention on International Trade in Endangered Species of Wild Fauna and Flora” (2000) as a threatened cetacean.

On the Brazilian coast, there have been few behavioral studies of this same species. Andrade et al. (1987) named and described some patterns of behavior of the S. guianensis in Guanabara Bay (Rio de Janeiro, Brazil); Monteiro-Filho (1991) analyzed their fishing strategies in Cananéia (São Paulo, Brazil); Oliveira et al. (1995) made a similar study to Andrade et al. (1987) and attempted to correlate the appearance of the animals in Mucuripe Bay (Fortaleza, Brazil) with the tidal cycle; Geise et al. (1999) included a relatively large amount of information describing and discussing the behavioral activity of young and adult individuals, group size and time of occurrence. These pioneer studies were essential to arouse the interest of the scientific community and to transmit the first information about the behavior of this species. Nevertheless, they are the first studies with this subject, they lack the overlapping coverage and agreement on terminology which would guarantee reproducible results.

This paper will aims to enlarge our knowledge of the behavioral repertoire of the estuarine dolphin at Dolphin Bay (Pipa, Tibau do Sul, Rio Grande do Norte, Brazil), giving special attention to group size, tidal cycle influence in their appearance and behavioral pattern.

\section{Material ANd Methods}

The village of Pipa is situated in Tibau do Sul $\left(6^{\circ} 10^{\prime}\right.$ 's; $\left.35^{\circ} 05^{\prime} \mathrm{W}\right)$, 86 km south of Natal, capital of the state of Rio Grande do Norte (fig. 1). Tibau do Sul has approximately $16 \mathrm{~km}$ of coastline, and it is very visited for tourists, especially during these observations on the Dolphin Bay. This bay is known traditionally by the local fishermen as "Praia do Canto" or "Praia do Curral". 


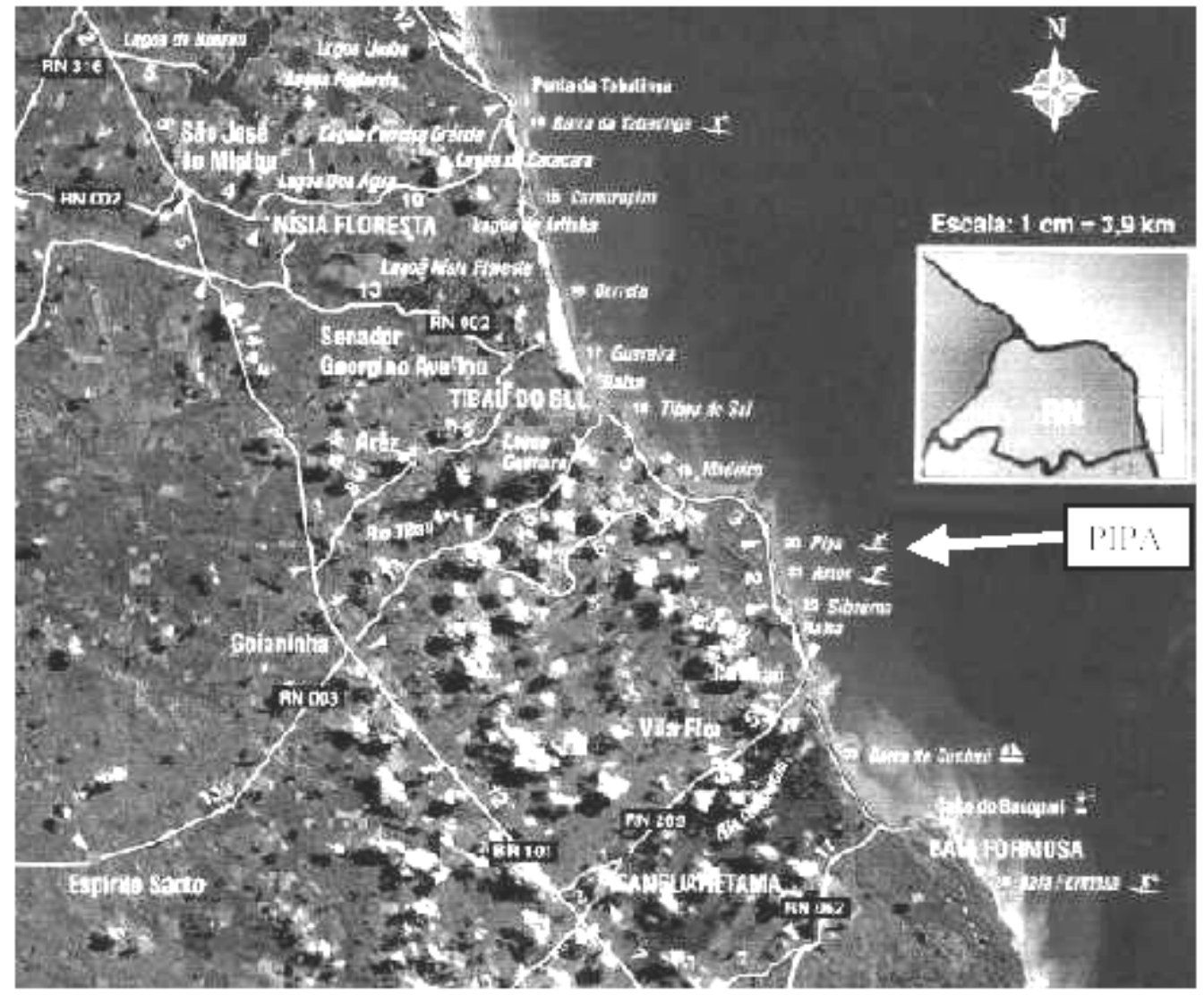

Figure 1 - Dolphin Bay, Pipa Beach, Tibau do Sul, Rio Grande do Norte, Brazil.

This bay, where normally occur the estuarine dolphin, has about $636 \mathrm{~m}$ wide and it is sheltered by vertical cliffs of clay, sandstone and limonite, which are part of the "Grupo Barreiras". The "Grupo Barreiras" is a sedimentary formation, typical of the Northeastern Brazil's coastline. The cliffs reach a height of some 40 meters but are topped in places by fossil sand dunes which raise the total height to an imposing 70 meters. In some places the rock, which is subject to severe weathering by the rain, is protected from the sea by sand deposits and vegetation. In others parts there is an active erosion process caused by the waves. The north face of the Dolphin Bay and the cliffs help to protect the beach and water from the force of the southeast trade winds, so evident on the less sheltered beaches to the other side of Pipa village.

The data were grouped in two seasons: rainy (March-August) and dry (SeptemberFebruary).

The observations were made from the main lookout (located halfway up a cliff about $40 \mathrm{~m}$ high) in the center of Dolphin Bay, and also from the beach, within the Pipa Ecological Sanctuary.

At the eastern end of the bay, there is a fish corral (large bottle-shaped trap made of stakes driven into the seabed forming a palisade). The dolphins seem to make use of this artificial feature

Tropical Oceanography, Recife: v. 31, n. 2, p. 101-112, 2003. 
in the environment by leading the fishes to its surroundings, where they can more easily be cornered.

From September to November 1994, an “ad libitum” (Lehner, 1979) sampling was carried out. All the activities performed by the estuarine dolphin were observed individually and in group. This information was registered manually on tables containing the types of conduct observed.

For the analysis itself, observations were carried out one weekend a month in 1995, one weekend every two months in 1996, and one week a month in 2000, during the period of daylight between 6:00 am and 5:00 pm. The observations totalized 360 hours, of which the animals were visible for 320 hours.

The following data was noted in standardized field files: date; time of the dolphins' arrival and departure from the bay (taken as the time of the first and last visualizations); weather conditions; variation in conduct every fifteen minutes, indicating type and frequency of each item of behavior and also if it was performed by a young animal or an adult, and other observations (any other relevant data not mentioned above).

The criterion for separation of the animals into adults, juveniles and calves was the size and the coloration as proposed by Geise et al. (1999): juveniles measuring $1 / 2$ to $3 / 4$ of adults, and calves not exceeding $1 / 4$ of the adult size. Besides, the young ones present a pink coloration on the belly and on the lateral portion up to the back fin. The gray color of the back is dark in the adults and clear in the young. In the results presented here concerning immature animals, all will simply be denominated "young", because of the difficulty in identifying accurately whether they were calves or juveniles.

It is important to stress that there was no prolonged observation of a determined individual. All animals were equally subject to having their behavior registered at the moment they were spotted. Therefore, if three estuarine dolphin were in the bay at a specific time, the activities of all three were registered, leaving to the observer only the differentiation related to age. This method is similar to the one called "all occurrences" (Lehner, 1979).

The statistical analysis of the data, a non-parametrical Mann-Whitney $U$ Test statistical method was used (Siegel, 1975). The significance level used was $\mathrm{p}=5 \%$ (two-tailed).

\section{RESULTS}

In 98 occasions, in which Dolphin Bay was visited to observation, only in 10 (10.2\%) was not registrated the occurrence of Sotalia guianensis. The number of animals spotted varied between one and eight (fig. 2).

A significantly greater number of estuarine dolphin was observed in Dolphin Bay in the morning period $(\mathrm{n} 1=47 ; \mathrm{n} 2=51 ; \mathrm{Z}=-2.2 ; \mathrm{U}=886.0 ; \mathrm{p}=0.02) ;(\mathrm{n} 1=47 ; \mathrm{n} 2=51 ; \mathrm{Z}=-2.2 ; \mathrm{U}=881.5$; $\mathrm{p}=0.02$ ), (fig. 3).

The average size of the group that entered the bay in the dry season was 2.75 estuarine dolphin and was not significantly different from the rainy season, when an average of 2.71 entered the bay (n1=7; n2=10; $Z=-1.0 ; U=24.0 ; p=0.28$ ) (fig. 4).

In relation to the tide, it was observed that ebb tide presented the greatest number of animals (about 2.6 individuals), while high tide presented the lowest mean value (about 1.3 individuals). The difference between them is significant ( $1=23 ; \mathrm{n} 2=59 ; \mathrm{Z}=-3.0 ; \mathrm{U}=392.5 ; \mathrm{p}=0.002$ ) (fig. 5).

In 36 of the 88 occasions (40.9\%) in which the entry of dolphins into the bay, was observed, young were spotted. The number of young ranged from one to three individuals, the most frequent number being one. The highest number of young was observed in February (average number 1.75) and August (average number 1.25).

Tropical Oceanography, Recife: v. 31, n. 2, p. 101-112, 2003. 
The observations showed eight behavioral patterns: feeding (chase and prey manipulation), leaps (total, partial and somersaults), tailslap, spy-hopping and surfing.

The chase conduct was more frequent (26.6\%) than all others (fig. 6). The predominance of chase was considerably greater in the ebb and flood tides than in the low tide (n1=6; $n 2=148 ; \mathrm{Z}=-$ 2.3; $U=198.5 ; p=0.02)$; ( $1=6$; $n 2=120 ; Z=-2.2 ; U=166.5 ; p=0.02$ ), (fig. 7).

Considering the behavioral sequences with and without young, significant differences were observed. The somersaults ( $1=31 ; n 2=61 ; Z=-4.3$; $U=434.5 ; \mathrm{p}<0.001)$, tailslap $(n 1=34 ; n 2=40 ; Z=-$ 6.29; $U=108.5$; $\mathrm{p}<0.001$ ), prey manipulation ( $\mathrm{n} 1=49$; $\mathrm{n} 2=52$; $\mathrm{Z}=-4.5 ; \mathrm{U}=607.0 ; \mathrm{p}<0.001$ ), spyhopping (n1=22; $n 2=32 ; Z=-3.2 ; U=170.0 ; \mathrm{p}<0.001)$ and total leaps (n1=24; $n 2=27 ; Z=-3.4$; $\mathrm{U}=139.5$; $\mathrm{p}<0.001$ ) presented greater indices with the participation of the young.

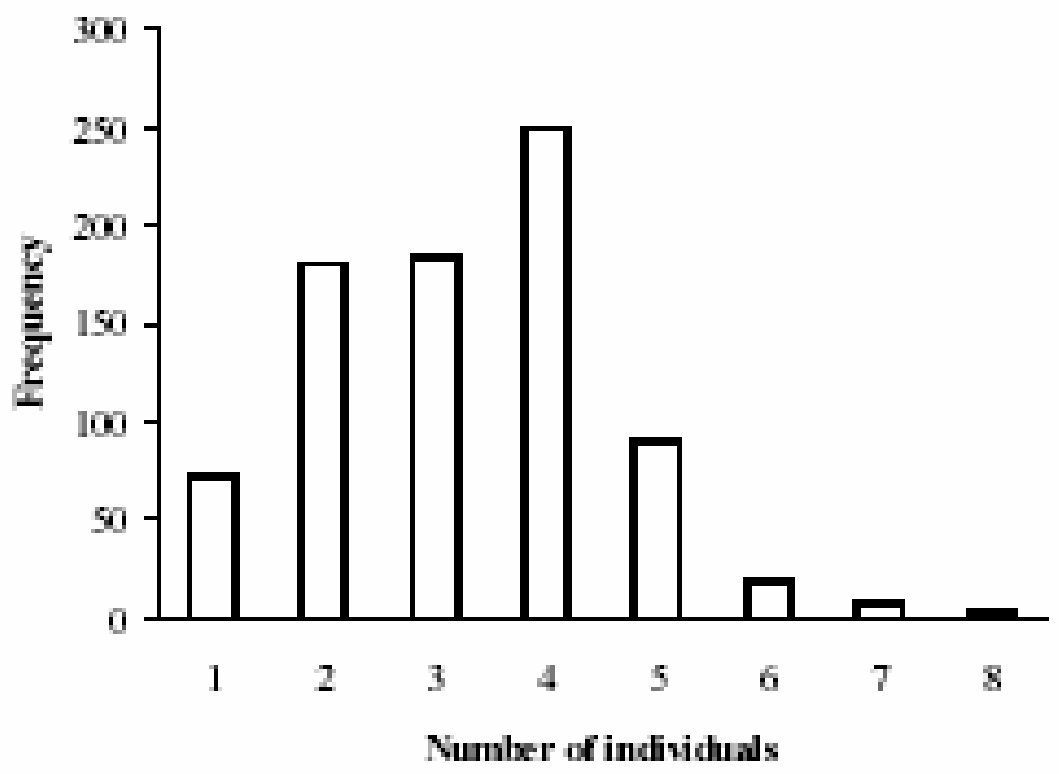

Figure 2 - Sotalia guianensis group sizes observed and their frequencies (sample size " $n$ " for each group size indicated above bars).

Tropical Oceanography, Recife: v. 31, n. 2, p. 101-112, 2003. 


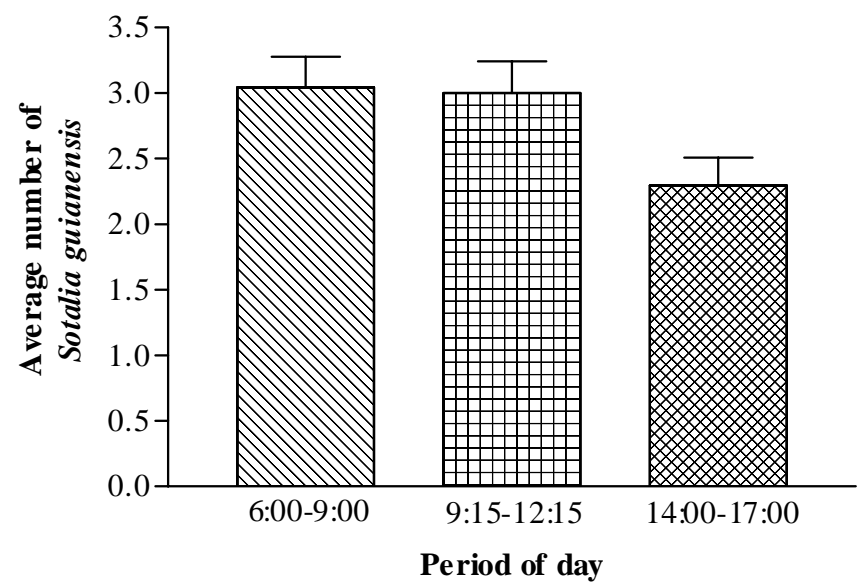

Figure 3 - Relation between period of day and the average number of Sotalia guianensis observed in the Bay. $n_{1}=47 ; n_{2}=51 ; Z=-2,2 ; U=886,0 ; p=0,02$ (6:00-9:00 x 14:00-17:00); $\mathrm{n}_{1}=47 ; \mathrm{n}_{2}=51 ; \mathrm{Z}=-2,2 ; \mathrm{U}=881,5 ; \mathrm{p}=0,02(9: 15-$ $12: 15 \times 14: 00-17: 00)$.

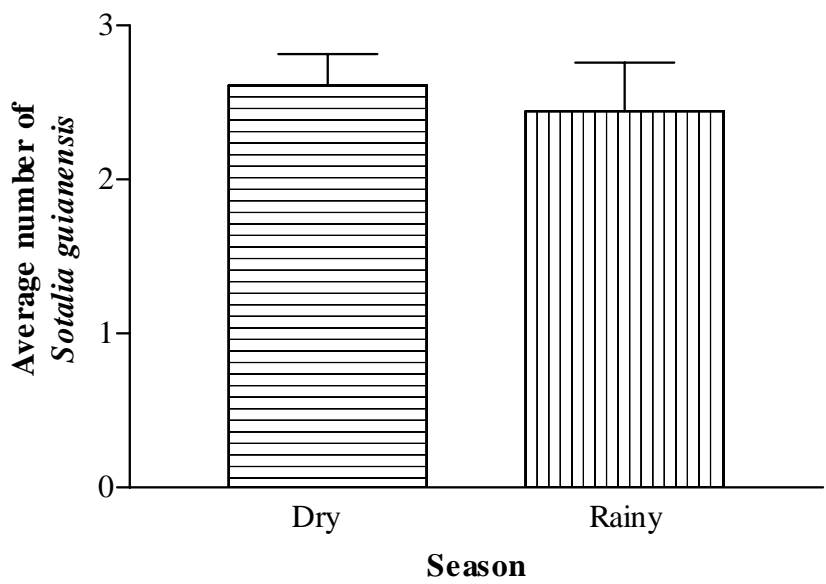

Figure 4 - Relation between season and the average number of Sotalia guianensis observed in the Bay. n1=7; n2=10; Z=-1,0; $U=24,0 ; p=0,28$. 


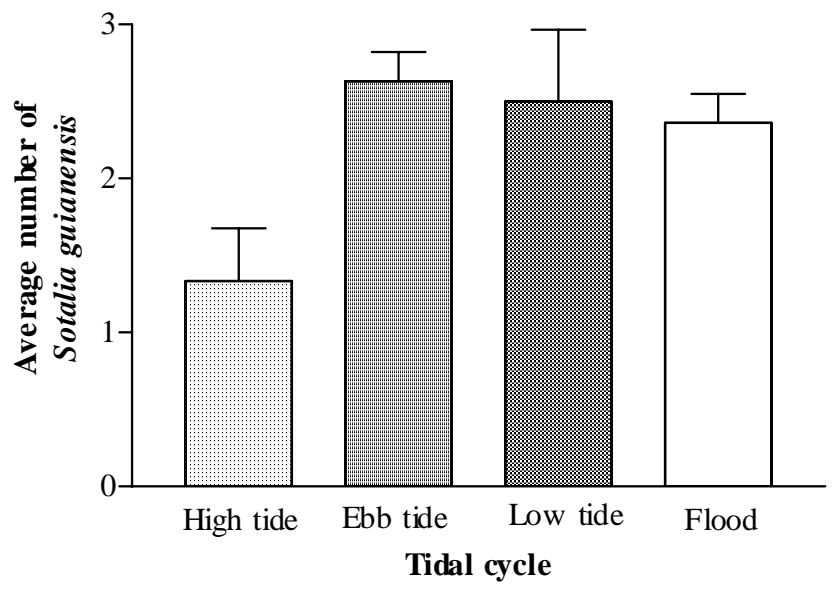

Figure 5 - Relation between tidal cycle and the average number of Sotalia guianensis observed in the Bay. n1=23; n2=59; Z=-3,0; $U=392,5 ; p=0,002$ (High tide $x$ Ebb tide).

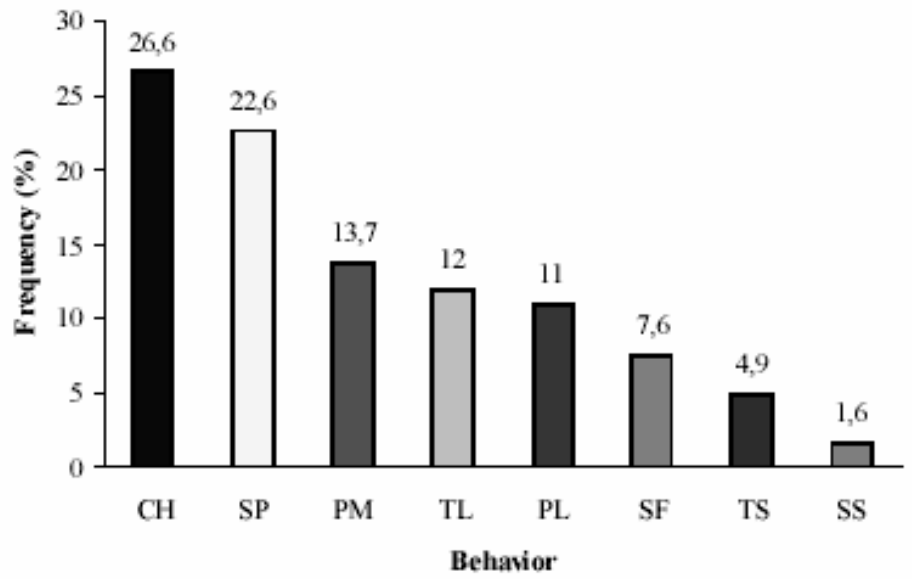

Figure 6 - Observed frequencies of the eight behavioral patterns; $\mathrm{CH}=$ chase, $\mathrm{SP}=$ spy-hopping; $\mathrm{PM}=$ prey manipulation; $\mathrm{TL}=$ total leaping; $\mathrm{PL}=$ partial leaping; $\mathrm{SF}=$ surfing; $\mathrm{TS}=$ tailslap; SS = somersaults 


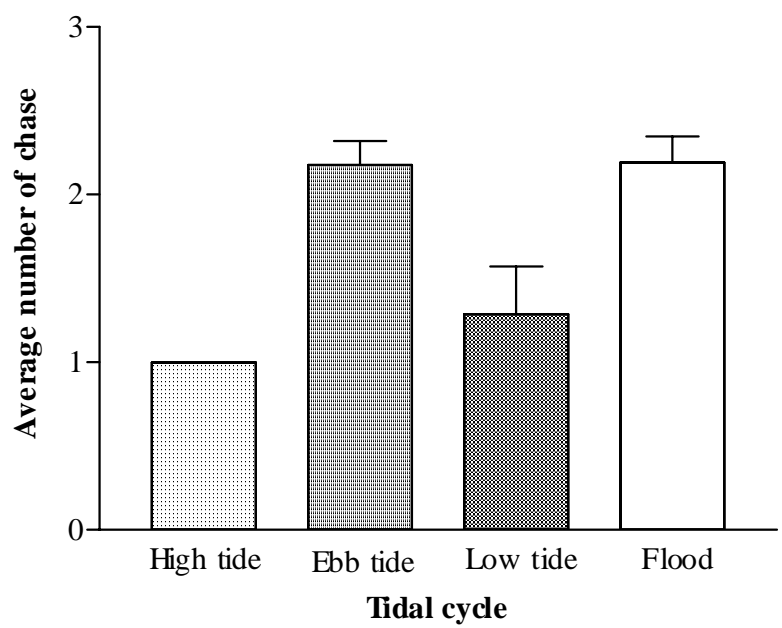

Figure 7 - Relation between tidal cycle and the average number of chases observed in the Bay. n1=6; n2=148; Z=-2,3; U=198,5; p=0,02 (Low tide $x$ Ebb tide); n1=6; n2=120; Z=-2,2; $\mathrm{U}=166,5 ; \mathrm{p}=0,02$ (Low tide $\mathrm{x}$ Flood).

\section{DISCUSSION}

The size of the Sotalia guianensis group presented in the Dolphin Bay (RN) ranged from 1 to 8 animals/day. A similar group size was observed in Cananéia (Geise, 1989), in Mucuripe Bay (Oliveira et al., 1995) and in North Bay (Rossi-Santos, 1997). On the other hand, there are records of greater group sizes in Todos os Santos Bay (Bittencourt et al., 1997), Sepetiba Bay (Simão et al., 1998) and Ilha Grande Bay, including a group formed of at least 450 estuarine dolphin (Lodi \& Hetzel, 1997).

According to Reis \& Queiroz (1992) the high number of individuals can mean a behavior of convergent migration to the area in question, where the sexual intercourse activity is the main cause. Hetzel \& Lodi (1993) believe that larger groups can be formed in pursuit of a common activity, for example, feeding.

In this study, the most of $S$. guianensis was observed during the morning. The estuarine dolphin would come to Dolphin Bay to feed, using the presence of the fish corral to aid in the capture of their prey. They would swim in the afternoon period to the nearest cove, known as Praia do Madeiro, which would be used as a resting area. It is necessary to carry out more research in Praia do Madeiro, to know what the most frequently performed activities are in this bay and if it is the preferred spot for resting, or if only a division of the population occurs and the estuarine dolphin use both two bays with the same purpose. Bossenecker (1978) observed groups of Sotalia guianensis moving between different areas for specific activities. Oliveira et al. (1995) suggest a pattern of movement between probable feeding areas on Iracema Beach (CE) and a rest area on Mansa Beach (CE).

In relation to the weather factor, possibly food is available in Dolphin Bay the whole year round, regardless of the season, thus, justifying the fact that there was no meaningful difference between the dry and rainy seasons. Geise (1989), observed that in Guanabara Bay (RJ), the

Tropical Oceanography, Recife: v. 31, n. 2, p. 101-112, 2003. 
estuarine dolphin were observed in greater numbers during the winter months (33,5\%), while in the Cananéia region (SP), the greatest number of animals was seen in the summer (34\%).

Higher numbers of animals were recorded at low tide, followed in order by the ebb and flood tides, which presented closely similar values. Higher occurrence of the chase conduct at low and ebb tides suggests that lower water volumes facilitate the capture of prey by the estuarine dolphin, why the fish are more concentrated. Geise (1989) registered an increase in the number of dolphins up to 4 hours after high tide (ebb) and low tide (flood) in Cananéia (SP). For Iracema (CE), Oliveira et al., (1995) registered higher frequencies during low and ebb tides. According to these authors, this pattern could be related to the abundance of fish at the place, which is probably greater in the ebb and low tides since the lower amount of water would facilitate capture of prey, corroborating the present work.

The "chase" behavioral pattern seems a good strategy for individual fishing, being the most efficient way to capture the prey when there are few individuals in the Bay. That is why, when there is a greater number of estuarine dolphin, they drive the shoal of fish to a certain spot and encircle it, which makes capture easier, avoiding the need to use the energetic chase conduct to catch the prey. Still regarding the chase activity, Geise (1989) describes it in the following way: "predatory behavior characterized by long dives and chasing at high speed, when the dolphins swim sideways, with their belly upwards or in a normal way". This procedure was denominated by Geise (1989) as lateral attack (lateral feeding). Monteiro-Filho (1991) designated it "chase in a declivity area" based on the fact that hunted fish normally seek protection in shallow waters, but when they are chased at high speed with the dolphin blocking their way they have no option but swim towards the channel, at which moment the dolphin dives onto the trapped shoal, making a big splash on the surface.

The above-mentioned authors describe some aspects for the chase which were also observed in this research, such as the increase in speed by the estuarine dolphin with the intention of capturing the prey. On the other hand, a difference was noted on comparing the studies carried out in Dolphin Bay (RN) with the one in Cananéia Region (SP) (Monteiro-Filho, 1991): while in the latter, the estuarine dolphin remained between the beach and the shoal, in the former they chased the shoal towards the beach.

As for the definition given by Geise (1989), it severely restricts the conduct, assuming that it necessarily happens sideways, which it was not always the case. Also, the term given by MonteiroFilho (1991) is unnecessarily long and could simply be abbreviated to "chase."

The behavior "prey manipulation", was observed many times, mainly when the young were present, which could indicate that this behavior is related to games or even teaching. In the present study, on most occasions ingestion of the food occurred, which it can characterize as feeding behavior. However, Geise (1989) describes a similar behavior, where the young threw something from one side to another and she assumed that this conduct was related to play.

Prey manipulation can also be directly related to learning. In general, the manipulation is accomplished by the adult in the presence of the young, which could represent the teaching of a feeding activity. This is the most common way of teaching among animals, when an individual performs its tasks in the presence of others, which have not yet learned about that activity (Souto, 2000). This behavior can also indicate that the adult is facilitating the ingestion of the food. By beating the fish against the surface of the water, it could be softening or killing the prey so that it can be easily swallowed by the young. It can also just represent play between adults and young.

The "tailslap" and "leaps" can be related to the feeding activity and serve to force the shoal of fish towards the shore, which would facilitate capture. Geise (1989) has already related these behaviors to the feeding activities.

At Dolphin Bay (RN), the "spy-hopping" behavior can be related to the turbidity of the water, which would induce the estuarine dolphin to use it with relative frequency in order to see the

Tropical Oceanography, Recife: v. 31, n. 2, p. 101-112, 2003. 
Bay more clearly. It may also be simply motivated by the curiosity of the estuarine dolphin about the environment, where they inhabit. According to Terry (1983), in captivity, Sotalia raises its head when people are near the swimming pool, which seems to be motivated more by food solicitation than curiosity.

The "surfing" behavior is considered a kind of movement that requires little energy release or is just a game (Andrade et al., 1987).

The presence of young was constant in Dolphin Bay (RN). They were always spotted in the presence of adults, swimming alongside them, suggesting a close social relationship between them. In the present study, young were more frequently seen in February, the same being noted by Rosas (2000), which indicates that there is no defined time for the birth of estuarine dolphin on the coast of Paraná state, although the births seemed to occur in greater number in the summer months (December and March). In Cananéia and Guanabara Bay, Geise (1989) also spotted a greater number of calves in the summer and the greatest occurrence was in January.

In a general way, the behavioral patterns of the adults and the young at the bay were similar, contrary to the experience of Rautenberg (1999) who registered striking differences between the two when observing specific calf conducts.

The spy-hopping conduct, total leaping, prey manipulation, tailslap, and somersaults presented a greater frequency with the participation of the young at Dolphin Bay. On the basis of these observations and the data quoted in the literature, these types of behavior are very likely to be related to games played by the young, the same being observed by Geise (1989) in Cananéia and Guanabara Bay, which it suggests that this occurs because it is the young, that they are almost always playing.

It is important to carry out further research to learn more about this species (such as feeding habits, reproduction, the impact of tourism, photo-identification, bioacoustics and night conduct), which should supply data that would describe with better accuracy the ethology of Sotalia guianensis in this region.

\section{ACKNOWLEDGEMENTS}

We would like to thank Liliane Lodi and Fernando Rosas for valuable support. The facilities provided by the Pipa Ecological Sanctuary were greatly appreciated. Thanks to David Hassett who reviewed and improved the English. Financial support was provided by the CNPq.

\section{REFERENCES}

ANDRADE, L.; SICILIANO, S.; CAPISTRANO, L. Movimentos e atividades do boto Sotalia guianensis (CETACEA, DELPHINIDAE) na baía de Guanabara - Rio de Janeiro. In: REUNIÃO DE TRABALHO DE ESPECIALISTAS EM MAMÍFEROS AQUÁTICOS DA AMÉRICA DO SUL, 2., 1987, Rio de Janeiro. Anais... Rio de Janeiro: Fundação Brasileira para a Conservação da Natureza, 1987, p. 49-55.

BITTENCOURT, A. R. M.; CARDOSO, C. P.; SANTOS JÚNIOR, L. R. Estimativa populacional, distribuição e abundância de Sotalia fluviatilis Gervais, 1853, na baía de Todos os Santos, a partir de filmagens. In: ENCONTRO DE ZOOLOGIA DO NORDESTE, 11., 1997, Fortaleza. Resumos... Fortaleza: Sociedade Nordestina de Zoologia, Universidade Federal do Ceará, 1997, p. 74.

BOSSENECKER, P. J. The capture and care of Sotalia guianensis. Aquatic mammals, v. 6, n. 1, p. 13-17, 1978.

Tropical Oceanography, Recife: v. 31, n. 2, p. 101-112, 2003. 
CITES. Convention on International Trade in Endangered Species of Wild Fauna and Flora, Appendix I. Jul. 2000. Available at http://www.wcmc.org.uk/CITES/english/index.shtml. Accessed on 19th Jan. 2001.

DA SILVA, V. M. F.; BEST, R. C. Mammalian species: Sotalia fluviatilis. American Society of Mammalogists, n. 527, p. 1-7, may 1996.

GEISE, L. Estrutura social, comportamental e populacional de Sotalia sp. (Gray, 1886) (CETACEA, DELPHINIDAE) na Região estuarino-lagunar de Cananéia, SP e na Baía de Guanabara, RJ. 1989. 199 f. Dissertação (Mestrado em Zoologia) - Instituto de Biociências, Universidade de São Paulo, São Paulo.

GEISE, L.; GOMES, N.; CERQUEIRA, R. Behaviour, habitat use and population size of Sotalia fluviatilis (Gervais, 1853) (CETACEA, DELPHINIDAE) in the Cananéia estuary region, São Paulo, Brazil. Revista Brasileira de Biologia, v. 59, n. 2, p. 183-194, 1999.

HETZEL, B.; LODI, L. Baleias, botos e golfinhos: guia de identificação para o Brasil. Rio de Janeiro: Nova Fronteira, 1993. p. 156-162.

IUCN. The 2000 IUCN Red List of Threatened Species. 2000. Available at www.redlist.org Accessed on 20th March 2001

LEHNER, P. N. Handbook of ethological methods. Cambridge University Press, 672 pp. 1979.

LODI, L.; HETZEL, B. Uma grande agregação de botos-cinza (Sotalia fluviatilis) na baía da Ilha Grande, Rio de Janeiro. In: CONGRESSO NORDESTINO DE ECOLOGIA, 7., 1997, Ilhéus. Resumos... Ilhéus: UFBA, UESC, SNE, CEPLAC, 1997, p. 337.

MONTEIRO-FILHO, E. L. A. Comportamento de caça e repertório sonoro do golfinho Sotalia brasiliensis (Cetacea:Delphinidae) na região de Cananéia, Estado de São Paulo. 1991. 99f. Tese (Doutorado em Ciências Biológicas) - Instituto de Biologia, Universidade Estadual de Campinas, Campinas.

OLIVEIRA, J. A. de; ÁVILA, F. J. C.; ALVES JÚNIOR, T. T.; FURTADO-NETO, M. A. A.; MONTEIRO-NETO, C. Monitoramento do boto cinza, Sotalia fluviatilis (CETACEA: DELPHINIDAE) em Fortaleza, Estado do Ceará, Brasil. Arquivo Ciências do Mar, Fortaleza, v. 29, n. 1-2, p. 28-35, 1995.

RAUTENBERG, M. Cuidados parentais de Sotalia fluviatilis guianensis (Cetacea: Delphinidae), na região do complexo estuarino-lagunar Cananéia-Paranaguá. 1999. 51f. Dissertação (Mestrado em Zoologia) - Departamento de Ciências Biológicas, Universidade Federal do Paraná, Curitiba.

REIS, M. S. S.; QUEIROZ, E. L. Distribuição, observações e capturas acidentais de Sotalia fluviatilis (Gervais, 1853) na baía de Todos os Santos, Bahia, Brasil. In: REUNIÓN DE ESPECIALISTAS EN MAMÍFEROS ACUÁTICOS DE AMÉRICA DEL SUR, 5., 1992, Buenos

Tropical Oceanography, Recife: v. 31, n. 2, p. 101-112, 2003. 
Aires. Resumos... Buenos Aires: Fundación Australis, Museo Argentino de Ciencias Naturales "Bernardino Rivadavia”, 1992, p. 54.

ROSAS, F. C. W. Interações com a pesca, mortalidade, idade, reprodução e crescimento de Sotalia guianensis e Pontoporia blainvillei (Cetacea, Delphinidae e Pontoporiidae) no litoral sul do Estado de São Paulo e litoral do Estado do Paraná, Brasil. 2000. 145 f. Tese (Doutorado em Zoologia) - Departamento de Ciências Biológicas, Universidade Federal do Paraná, Curitiba.

ROSSI-SANTOS, M. R. Estudo quali-quantitativo do comportamento de alimentação do golfinho ou boto cinza Sotalia fluviatilis Gervais, 1853 (Cetacea, Delphinidae) na Área de Proteção Ambiental do Anhatomirim e Baía Norte de Santa Catarina. 1997. 76 f. Monografia (Bacharelado em Ciências Biológicas) - Departamento de Ecologia e Zoologia, Universidade Federal de Santa Catarina, Florianópolis.

SIEGEL, S. Estatística não paramétrica para as ciências do comportamento. São Paulo: Nacional, 1975. 350p.

SIMÃO, S. M.; SICILIANO, S.; PEREIRA, T. C. C. L.; PIZZORNO, J. L. A.; ENCARNAÇÃO, A. F.; SÃO SABAS, C. S. Caracterização de uso do habitat e comportamento do boto-cinza, Sotalia fluviatilis, na Baía de Sepetiba (RJ, Brasil). In: REUNIÃO DE TRABALHO DE ESPECIALISTAS EM MAMÍFEROS AQUÁTICOS DA AMÉRICA DO SUL, 8., CONGRESSO DA SOCIEDADE LATINOAMERICANA DE ESPECIALISTAS EM MAMÍFEROS AQUÁTICOS, 2., 1998, Olinda. Resumos... Olinda: Centro Peixe-boi/IBAMA, 1998, p. 207.

SIMÕES-LOPES, P. C. Sobre a ampliação da distribuição do gênero Sotalia Gray, 1886 (CETACEA, DELPHINIDAE) para as águas do Estado de Santa Catarina - Brasil. In: REUNIÃO DE TRABALHO DE ESPECIALISTAS EM MAMÍFEROS AQUÁTICOS DA AMÉRICA DO SUL, 2., 1987, Rio de Janeiro. Resumos... Rio de Janeiro: Fundação Brasileira para a Conservação da Natureza, 1987, p. 87-88.

SOUTO, A. Etologia: princípios e reflexões. Recife: Universitária/UFPE, 2000. 330p.

TERRY, R. P. Observations on the captive behaviour of Sotalia fluviatilis guianensis. Aquatic mammals, v. 10, p. 95-105, 1983. 